\title{
Architecture of Sovereignty: Bosnian Constitutional Crisis, the Sarajevo Town Hall, and the Mêlée
}

\author{
Elena Cirkovic ${ }^{1}$
}

Published online: 9 November 2015

(C) Springer Science+Business Media Dordrecht 2015

\begin{abstract}
This paper addresses the processes by which the international community intervened and participated in the defining of Bosnian identity and the corresponding constitutional framework, as well as the continuous paradoxical tension between the ethnic local and claims to universalism of supranational legal norms. In particular, the 1995 Constitution and the architecture of its sovereignty have been contested through provisions of the European Convention of Human Rights. The analysis is further supported by the discussion of the architectonic structure of the Town Hall/National Library in Sarajevo that has had an important constitutional role since the collapse of the Ottoman period. The paper thus focuses on two sites for construction/deconstruction of Bosnian sovereignty: the constitutional framework and the more concretely visible architectural symbol of the Town Hall/National Library. This importance of a visual and spatial approach to Bosnian realities is carried further by the 1993 'Eulogy' that Jean-Luc Nancy wrote for Sarajevo, as a site of the Mêlée.
\end{abstract}

Keywords Architecture - Bosnia and Herzegovina - European Court of Human Rights · History of public international law · Jacques Derrida · Jean-Luc Nancy · Sovereignty $\cdot$ Supranational citizenship

\section{Introduction}

The collaborative writings of two prominent post-Second World War Yugoslav architects, Dusan Grabrijan and Juraj Niedhardt, observed the role of the Ottoman heritage in the modern architectural expression of Bosnia and Herzegovina (BiH)

Elena Cirkovic

elenacirkovic@osgoode.yorku.ca

1 Department of International Relations, Bilkent University, FEASS A-303, Merkez Campus, 00680 Ankara, Turkey 
(Grabrijan 1983). From their perspective, a solution was needed for the tension in the relationship between the architecture of the Ottoman origin and architecture that would reflect a modern socialist society of the Yugoslav period. Indeed, Bosnian architecture has played a symbolic role in the broader processes of construction as well as destruction of national identities, and Grabrijan and Niedhardt's study describes the conflation among various influences on the local architectural, as well as political and cultural communication: the Ottoman presence, which in itself spanned cultures and continents; the Austro-Hungarian period; and the constitution of Bosnian and Yugoslav sovereignty.

Bosnian architecture continues to play a symbolic role in the contestation of local social life, sovereignty, and relationship with the global. The contemporary and historical discourses surrounding one particular object, the Sarajevo Town Hall, echo the changes, which took place through consecutive dominant sociopolitical models: colonialism, socialism, and post-war reconstruction in $\mathrm{BiH}$. As such, they have given temporary meanings to the Town Hall and its purpose in other social spheres of Bosnian life.

This paper addresses the processes by which the international community participated in the defining of Bosnian identity and the corresponding constitutional framework, as well as the continuous paradoxical tension between the ethnic local and claims to universalism of supranational legal norms. In particular, the 1995 Constitution $^{1}$ and the architecture of its sovereignty have been contested through provisions of the European Convention of Human Rights (ECHR). The analysis is further supported by the discussion of the architectonic structure of the Town Hall/ National Library in Sarajevo that has had an important constitutional role since the collapse of the Ottoman period. The paper thus focuses on two sites for construction/deconstruction of Bosnian sovereignty: the constitutional framework and the more concretely visible architectural symbol of the Town Hall/National Library.

It is now well documented that the constitutional electoral provisions in $\mathrm{BiH}$ are discriminatory under the Protocol No. 12 to the ECHR. The Bosnian Constitution emanates from an internationally imposed peace treaty, which cements, in law, differential citizenship along ethnic lines, and as such, challenges the terms of 'European' universality. The 2009 Grand Chamber of the European Court of Human Rights (ECtHR) decision in Sejdic and Finci v. Bosnia and Herzegovina (hereinafter 'Sejdic and Finci'), ${ }^{2}$ serves as the primary reference for these challenges. However, the international community's sui generis application of international norms is not novel and dates in part back to the Balkan Crisis of 1905.

The broader objective of this analysis is to observe general relationships between the local legal structures and international legal and political community through not only the analysis of the Bosnian constitutional development, but also through the accompanying symbols and images of social life. Architecture, in this sense, is

\footnotetext{
${ }^{1}$ Constitution of the Federation of Bosnia and Herzegovina, 18 March 1994, available at: http://www. refworld.org/docid/3ae6b56e4.html [accessed 31 May 2015].

${ }^{2}$ Sejdic and Finci v. Bosnia and Herzegovina, Application Nos. 27996/06 and 34836/06, Council of Europe: European Court of Human Rights, 22 December 2009, available at: http://www.unhcr.org/ refworld/docid/4b44a28a2.html.
} 
not only invested with meaning, but is also a means of conveying meaning. This importance of a visual and spatial approach to Bosnian realities is carried further by the 1993 'Eulogy' that Jean-Luc Nancy wrote for Sarajevo, as a site of the Mêlée (Nancy 2000). Nancy extended his critique and theory of community to include Sarajevo as a particularly envisioned space, which he observed to be disintegrating into communal ethnic conflict. But Nancy's observation of 'being-with' in an urban space does not provide a complete deconstructive analysis of several processes implicated in the Bosnian conflict. For this reason, the present analysis seeks support from Jacques Derrida's more fundamental challenge to legal, sovereign, and/or architectural structures, which reveals an intimate relationship between violence and law.

The paper is structured as follows. The first section discusses the constitutional crisis in $\mathrm{BiH}$ from the perspective of the ECtHR Sejdic and Finci judgment. It then glances at the simultaneous post-war restructuring of the Town Hall and how its present symbolism both effects and affects the image of social life in $\mathrm{BiH}$. Secondly, the analysis offers a historical outline of both Bosnian constitutional history and the history of the Town Hall. It argues that the parallels reveal how this architectural structure was meant to echo the socio-legal and political constitution of Bosnian society. This means that the Bosnian community owes its image not only to internal societal processes, but it also comes from broader imaginings of its essence. The final section refers to Nancy's discussion of Sarajevo as a former site of the Mêlée, which serves the purpose of his broader theoretical criticism of local communitarianism and ethnicization, but also creates yet another external imagination of the Bosnian reality as either the former Ottoman trading post (a crossroad and site of multiculturalism) or as a site of ethnic conflict. However, the ethnicization of $\mathrm{BiH}$ took place within the broader local-global framework, which needs to be further deconstructed and de-sedimented. Above all, these are all narratives of compromised sovereignty, which would also need to be surpassed by the ordinary Bosnians and Herzegovinians themselves, if $\mathrm{BiH}$ is to have any chance for substantive democratic reform.

\section{Constitutional Structure in BiH and the ECHR}

This section recapitulates the now widely discussed facts and judgement of the Sejdic and Finci case, which challenges the constitutional framework of a state (Cirkovic 2014). The Bosnian Constitution emerges from the architecture of the General Framework Agreement for Peace (GFAP) in BiH (hereinafter 'the Dayton Peace Agreement' or the 'DPA'), initialled in Dayton on 21 November 1995 and signed in Paris on 14 December 1995. In April 2013 the EU 'froze' the EU accession process for Bosnia due to the lack of commitment among Bosnian leaders over the constitutional reforms and implementation of the 2009 Sejdic and Finci decision. Two citizens of BiH, Mr. Dervo Sejdic and Mr. Jakob Finci of Roma and Jewish ethnicities respectively, brought applications before the ECtHR. The applicants complained of their ineligibility to run for the Presidency, and the House of Peoples of the Parliamentary Assembly election as stipulated by the Constitution 
of $\mathrm{BiH}$ and the corresponding provisions of the Election Act 2001, solely on the ground of ethnic origins.

The commentary on the international community's involvement in the Bosnian war is here limited to the Dayton and post-Dayton spaces. Much has been written on the compromised sovereignty of $\mathrm{BiH}$ in view of the extensive involvement of the international community in its post-war governing structures (Chandler 2000; Campbell 1998). In addition, the assignment of responsibility in the instigation of the Bosnian conflict is still subject of debate (Campbell 1998). As Robert Howse has argued, the major task in resolving some conflict situations is to prevent their escalation into an unstable competition among major powers:

All of the major powers and conflicting parties in Bosnia were actors in this game. A victory would be a negotiated agreement bringing the conflict to an end. An eruption of the conflict beyond the parameters of Bosnia and involving the major powers was to be avoided at all costs. (Howse 1995, p. 2)

This paper limits the critique insofar as it targets the recognition of ethnic claims as the only claims present in the territory. This process, as has been argued elsewhere, has silenced to a great extent the presence and claims of non-ethnic identities as well as of minorities not associated with the three constituting nations, which were recognized through the DPA. It is this final point that is the underlying implication of this analysis: the ability of local peoples to challenge both locally and internationally enforced identities.

While the powerful presence of ethno-nationalist interests during the DPA resulted in such a discriminatory constitutional structure, the ECtHR has ruled that the constitution presently runs counter to supranational human rights norms on discrimination. Surely, special norms might be applied to a situation for exceptional reasons, such as the termination of a violent conflict. This, however, does not preclude the perception on the part of the local population that universal norms, which seem to be accessible through supranational legal bodies, are also applicable to them. It also does not automatically allow derogation from general international norms.

Cases from $\mathrm{BiH}$, which were brought before the ECtHR after Sejdic and Finci with the same constitutional challenges, raise critical issues in relation to the sovereignty formation of $\mathrm{BiH}$, as well as the relationship between law and politics. On 15 July 2014 the ECtHR came to the same conclusion in Zornic v. Bosnia and Herzegovina (hereinafter 'Zornic' $)^{3}$ as in Sejdic and Finci. And, further, the application from 18 February 2014 of Pilav v. Bosnia and Herzegovina (hereinafter 'Pilav' $)^{4}$ raised the same critical issues of discrimination on the grounds of ethnicity.

In the Sejdic and Finci decision, the ECtHR applied for the first time the general prohibition of discrimination in Protocol No. 12 to the ECHR. It is also the first time that the ECtHR ruled on the violation of the ECHR by a state constitution (even if that constitution is an Annex to an international treaty). The decision, however,

\footnotetext{
3 Zornić v. Bosnia and Herzegovina, Application No. 3681/06.

4 Application No. 41939/07. Ilijaz Pilav against Bosnia and Herzegovina lodged on 24 September 2007.
} 
reveals an ambiguous stance of the ECHR framework in relation to $\mathrm{BiH}$ 's unorthodox state structure: it requires domestic recognition and implementation of ECHR norms, while recognizing the exceptional situation of the founding of institutions, which caused the suspension of those norms in the first place. In a way, ECtHR assumes that $\mathrm{BiH}$ has the sovereign prerogative to amend its own laws. However, this exceptional situation is related to the broader local and international political context in which the peace negotiations took place.

The ECtHR emphasized that where a difference in treatment is based on race or ethnicity, the notion of objective and reasonable justification must be interpreted as strictly as possible, as no difference in treatment that is based exclusively or to a decisive extent on a person's ethnic origin can be objectively justified in a contemporary democratic society that is built on the principles of pluralism and respect for different cultures (para. 44). Nevertheless, the ECtHR stated that Article 14 does not prohibit Contracting Parties from treating groups differently in order to correct 'factual inequalities' between them. In certain circumstances, a failure to attempt to correct inequality through different treatment may, without an objective and reasonable justification, give rise to a breach of that Article. Specifically, the Court reiterated that discrimination means treating differently, without an objective and reasonable justification, persons in similar situations. The scope of a Contracting Party's margin of appreciation in this sphere will vary according to the circumstances, the subject matter and the background.

While this differentiation between the constituent peoples and 'Others' had lost its objective and reasonable justification (para. 48), the exclusion rule pursued 'at least one aim which is broadly compatible with the general objectives of the Convention...namely the restoration of peace' (para. 45). The ECtHR correlated the nature of the conflict directly with the need to approve 'constituent peoples' and ensure peace. The ECtHR thus remained vague in its conclusion on the legacy of Bosnia's foundational compromise between peace building and the ethnicization of citizen's rights. This important tension was emphasized in the partly concurring and partly dissenting opinion of Judge Ljiljana Mijovic, joined by Judge Khanlar Hajiyev. Judge Mijovic asks, 'In my opinion, the key question that required an answer in this case is whether that tripartite structure was ever justified, and whether it continues to be justified' (para. 43, emphasis added). While Judge Mijovic points to legal contradictions of the supranational human rights system, the contradiction emerges from the allocation of $\mathrm{BiH}$ to a situation of anomaly, conflict, and emergency, where the usual understanding of anti-discrimination principles has been modified to fit the need for the cessation of conflict. By not addressing Bosnian constitutional origins, the ECtHR also avoids the discussion of any potential derogation from its supranational constitution. It leaves open the question whether emergency provisions that resulted in a treaty, emerged from legal black holes.

The ECtHR echoed the Sejdic and Finci decision in determining admissibility in Zornic. It replied to the Government's submission that $\mathrm{BiH}$ could not be held responsible for the contested constitutional provisions because the Constitution of Bosnia and Herzegovina was part of an international treaty, the DPA. The Court held that, leaving aside the question whether the respondent State could be held responsible for putting in place contested constitutional provisions, it could 
nevertheless be held responsible for maintaining them (para. 30). The ECtHR thus made no novel attempt to address the non-democratic nature and exceptional circumstances standing at the root of the constitution-making moment in $\mathrm{BiH}$. The extralegal measures became embedded in the Bosnian constitutional structure, even if they constituted a derogation from the broader human rights principles of the ECHR.

The overall contradiction of the international community's approach towards $\mathrm{BiH}$ is rightfully pointed out in Judge Mijovic's dissent. She provides a critique of the very foundational moment of the Bosnian Constitution. It is rooted in the violence of the civil conflict and its implemented as a measure ending this violence. However, as an emergency provision, it does not rest on procedures of democratic participation. In this sense, it conserves the original violence in that it sediments ethno-nationalist claims, which were at the root of the Bosnian conflict (Derrida 1990). Justice owed to the Bosnian peoples would include de-sedimentation of this legal framework, and accordingly the violence which caused it.

This is relevant for the continuing positioning of $\mathrm{BiH}$ within the international community. For instance, BiH's Stabilization and Association Agreement (SAA) with the European Union (EU) is set to finally come into effect, in the wake of a new Anglo-German initiative in $\mathrm{BiH}$, pushing the political establishment in Sarajevo to revive the country's stalled Euro-Atlantic integration process. However, EU member states cannot prevent BiH's own citizens from serving on the country's presidency, among other official bodies, because of their ethnic background, nor can they tolerate the now increasing presence of segregated schools. $\mathrm{BiH}$, as defined by the Dayton constitutional order, would compromise the self-image, as well as effectiveness, of both the EU or NATO and would not be able to join either institution before major constitutional reforms are enacted. This does not absolve the responsibilities of the Bosnian government and constituency. But, the ECtHR's paradoxical and simultaneous recognition of the Bosnian citizens' claims and upholding of the constitution's origins through the DPA, pose a question regarding the type of community that has been envisioned and/or recognized in $\mathrm{BiH}$.

What became of the local legal and political structures during and after the DPA was not a purely sovereign decision in the sense that it did not rely on the democratic legitimacy granted to it by the local peoples. Rather, it was as much the decision of the international community, which was in charge because of the inability of the local sovereign to end the violence. The type of sovereignty that was accorded to $\mathrm{BiH}$ corresponds thus more to past emergency provisions and interventions in the Balkan region, rather than to the contemporary human rights claims and institutions such as the ECHR. The emergency provisions did respond to real security concerns. Nevertheless, the Bosnian peoples did not participate in the constitution-making process but rather remained visible only as participants in, and victims of ethnic violence. The apparent Bosnian legal exceptionality in the supranational human rights framework needs to be contextualized within the broader imagination of the 'Balkans', as well as the manner in which this imagination became manifested in diverse societal languages. 


\section{Sarajevo Town Hall and the Visualization of Bosnian Society}

The post-war reconstruction process also witnessed the need for rebuilding of infrastructure and restructuring of Bosnian urban spaces. But the ambiguities that accompanied its constitutional architecture also resonated in other spheres. In the Bosnian context, visual and architectural representation played an important role in the narratives of local political changes, as the world witnessed through the media the destruction of its architectural heritage during the 1990's conflict. The comparison of languages (legal and architectural) serves to show how local and international processes converge in the current constitutional Bosnian crisis.

The architectural model has been a metaphor for a kind of thinking which may not necessarily be architectural (Derrida 1986, 1997; Derrida and Eisenman 1997). For Derrida, for instance, the deconstruction of architecture is the deconstruction of the political. In the Bosnian case, it is also legal. Each language proposes an arrangement in space. To share in the more formal legal space of specific and prescribed activity means to be identified by assumed pre-existing frameworks, such as common culture, ethnicity, religion, race, and other binding adjectives. Such frameworks are similarly recognizable in the visual representations of a space and its identity.

The assumption that architecture is a communication system conveying its function in the broader society through 'form' and 'function' is not novel. In particular, Jenks has argued, 'architectural objects, besides permitting and promoting certain functions, [...] permit and promote critical readings, in which one compares them with prior (and subsequent) means of societies' ideologies and inhabitation'. The destruction of the Sarajevo Town Hall during the 1992-1996 war added to it an 'aureole of suffering'. In the context of the post-war reconstruction, the rebuilding of the Town Hall appeared to be a question of a recovery of the nation's entire history. The local and international calls for its rebuilding gained extensive press coverage. This included, for instance, organizing of events amidst the ruins of the Town Hall, such as the Sarajevo Symphonic Orchestra and Chorus performance of Mozart's Requiem in June 1994, conducted by Zubin Mehta. Initial support for the rebuilding was provided by international organizations such as UNESCO and the World Bank. Still, the Austrian Government and the EU funds only provided for a partial recovery of the building, delaying the process. The project was eventually completed in 2014, for the commemoration of World War I.

The architectural features of the Town Hall are more relevant for the Bosnian past than its present. In the process of determining the cultural value of the building and the collective memory of the city, the UNESCO 1997 decision declared the Town Hall 'the world monument of the interethnic peace' and placed the building under UN monument protection. But despite the celebrations of the building's current standing, the initial origins of the Town Hall are in the Austro-Hungarian Empire's presentation of the building as a symbol of foreign dominance that aimed at reaching out to the local population (Alic 2012). The main obstacle to swift completion of its recent reconstruction was the difficulty in aligning its presence 
with any of the local ethnic or religious groups. At first, it was not even clear who owned the building. Because it functioned as a National Library in the Yugoslav period, a consultant engaged by the Austrians to assess the project deemed the National Library the legal owner. However the Canton of Sarajevo continually referred to the building as its Town Hall. The reconstruction came to a halt a couple of times. In March 2012 it finally received EU pre-accession funding, with EU Special Representative to Bosnia-Herzegovina, Peter Sorensen, commenting that as a way of 'overcoming the wounds of the past, cultural heritage protection and promotion has the potential to be of real support to and a catalyst for better interethnic and intercultural understanding in the future' (Sorenson 2012).

The understanding of that future, however, also requires an understanding of the past, and the more endemic exceptionalism of the so-called Balkan region, at least as it has been situated in both global and local imagination. The obscurity of the Town Hall's relationship to its surroundings is echoed in the similar ambiguity in the international community's involvement and envisioning of Sarajevo and $\mathrm{BiH}$. In order to understand the ambiguities in the current reconstruction processes, it is important to understand the historical envisioning of Bosnia as a sovereign entity, its constitutionalism, as well as its cultural symbols.

\section{The Balkan 'Crises' and Building of Sovereignty}

As soon as sovereignty is in play, says Nancy, its demands inevitably go all the way and thus to the very end ('jusqu'au bout'), that is, it demands to be realized in full and to be completed. The fullness of sovereignty also means death, destruction, and sacrifice of its constituents (Nancy 2001, p. 115). In the 'Abandoned Being' Nancy describes the law of 'abandonment' as that which exists as the 'other' of the law. This law is a voice, which 'constitutes the law, to the extent that it orders' (1993, p. 45). This ordering can be seen as the setting of a limit, beyond which exists an unfathomable outside. Outside of the 'limitless severity' of the law to which being is abandoned, this being remains elusively and constitutively beyond reach. But law and sovereignty mutually constitute one another, with the violence that brings them into being, and the chaotic moment of exception, which might exist just before the law (Derrida 1990, p. 927).

To be done with sovereignty requires confronting in the first place the violence that traditionally rests at its foundation, the emergence of states through political action and agitation, colonialism and invasion, where the rule of law is almost always ex-post facto. In international legal terms, this has meant a transition from fact to law. The exceptionality of certain geographies, however, appears to prolong the pre-legal violence at various stages of its history. One such stage was the Balkan Crisis of the early twentieth century. In 1905, British jurist John Westlake became the president of the British Balkan Committee (1903-1913). The Committee was formed due to concerns over the uprisings in Macedonia against the Ottoman Empire, and the possibility that 'Balkan' problems could become 'European' problems. Until then, the Balkans were part of the multicultural pax ottomanica, but the emergent nationalist claims required a re-imagination of the region according to 
specific national borders. The Committee offered its 'expertise', and made policy recommendations. In this capacity it required an expert whose reputation as an authority on international law might add 'weight and importance to the opinions and acts of the committee, and secured for them attention both at home and abroad'. The Secretary of the Committee, Arthur J. Symonds, wrote in his contribution to the Memoirs of John Westlake (1914), that the Committee was accused of being 'an irresponsible body, with no special knowledge of the past history or present conditions of the Balkan countries, such as would entitle them to claim authority for their opinions' and that 'they were blinded by racial and religious prejudice against the Turks...that they were "sentimentalists"'. Westlake saw the situation somewhat differently. In his 1906 article, 'The Balkan Question and International Law', he argued that 'extreme misgovernment in Turkey was a nuisance to the neighbouring States', and warranted international attention. Moreover 'if the Sultan could not keep order in his own dominions, or if to keep order he had recourse not to civilized means of repression but massacre, he lost all claim to be regarded as a ruler to whom international law could apply'.

The moment when international law was being applied to the Sultan's dominion was contingent upon European recognition of the Ottoman Empire as belonging to the same law among nations. The nineteenth century European conceptualization of the Orient emerged together with the liberal understanding of international law, the simultaneous rise of nationalism and the unitary nation state. In 1894, Westlake wrote that Turkey held an 'anomalous position... included on account of its geographical situation in the political system of Europe, but belonging in other respects rather to the second group of contrasted populations' and that her admission via the benefit of international law 'cannot react on the statement of the law, which is what it is because it is the law of the European peoples' (Westlake 1894, p. 103). In other words, if universal law among nations applied outside Europe, it was intrinsically inferior to European international law. ${ }^{5}$ The non-European world would include the Turks or the Saracens, as trade partners, enemies at war, or simply a problematic geographic place, which could constitute a threat to international security if not carefully managed. Thus, the intervention, which Westlake found to be warranted, still included the Ottoman Empire within the realm of international law, albeit as not always capable of performing its duties. England's intervention in the Balkan Crisis was necessary for it had 'as much at stake' in this case as it had 'in all parts of the earth'; or, more specifically, intervention was 'justified by any sane view of international law'.

\footnotetext{
5 This is now a well-established argument among scholars who have been critical of international law's constituting process (Wallerstein 1976; Anghie 1996; Kennedy 1996; Koskenniemi 2001; Simpson 2004; Orford 2014). Some, however, have focused on particular modifications that international law underwent in situations of exceptionality. Umut Özsu concludes that forced population exchanges between Greece and the Turkish Republic in the 1920s were not a phenomena of particular space and time; rather, they became both an exception and a sui generis precedent (Özsu 2013). He further argues that non-Western policymaking has been subordinated to a fundamentally Euro-American international order 'one whose constituent elements may be contested but whose loci and axes of power are unmistakable' (2013). See also, Lorimer (1883), for a tripartite division of international 'humanity' that included his definition of 'semi-civilized' states.
} 
This expression was not mere Eurocentrism, but pertained to a series of considerations concerning stable states of affairs, economics, geopolitical and security concerns in relation to other empires, and the particular understanding of the 'exceptional' as volatile and non-western. Moreover, as the century progressed without a supranational government, European professional diplomats and jurists became the primary codifiers of standards of the international community and 'the legal conscience of the civilized world' (Koskenniemi 2001, p. 11, 2011). Such discourses served to reinforce a particular self-perception of both the international political and legal community.

The major European powers feared that the instability of the Ottoman regime would shatter the precarious balance of power in European politics. The peoples who belonged to the Ottoman Dar al Islam now needed to be reconstituted in accordance with imperatives of the modern nation state. The crumbling Ottoman Empire had already attempted to 'modernize' its multicultural domain through edicts such as the Nationality Law of 1869, which would start determining legal definitions of belonging. Carl Schmitt would eventually argue in reference to Turkey's expulsion of the Greeks, that the 'eradication of heterogeneity', was evidence of 'actual democracy' (Schmitt 2003 [1950] p. 409). The Bosnian case became another example of a space where local pluralities needed a narrative and corresponding visual coding of a nation.

Forms of representation along ethnic, religious, and nationalist lines were set in force with the Bosnian Constitution of 1910 that came into effect after the Annexation by Austria-Hungary in 1908. In order to distinguish the Bosnian population as belonging to a particular ethnic-religious community, the AustroHungarians had an interest in developing a specific national identity. "The Mêlée" section of the electoral Act introduced a system of proportional political representation of the so-called 'three main denominations'. Seats in State Parliament were divided among Serbian Orthodox members, Muslims, and Catholics, with one seat in the Second Senate set-aside for a Jewish representative (Art. 39, Bosanski Ustav 1910). The basic social structure had been tied to Bosnia's communal and religious order, which enshrined the participation of Bosnian citizens as determined by their ethnic and religious belonging. This was challenged with the establishment of the Kingdom of Yugoslavia and the Citizenship law of 1928, which established a single Yugoslavian citizenship for the whole territory of the Kingdom. $\mathrm{BiH}$ regained republican citizenship status during Socialist Yugoslavia with its divided federal and republican citizenship regime. When in 1943, Bosnia became one of six constituent federal units of the Socialist Federal Republic of Yugoslavia (SFRY), it differed from other Yugoslav republics, in that none of the three main ethnic groups had a majority. After the dissolution of SFRY in 1991-1992, creating a unitary state in $\mathrm{BiH}$ was again difficult, evoking the efforts of the international community from the times of the Balkan Crisis.

External self-determination of $\mathrm{BiH}$ presupposed the realization of the collective right to territoriality, formation of the classical nation-state, and internationally recognized sovereignty. However, the doctrinal purity of the right to external selfdetermination resulted in an ambiguous relationship between state building, nation, and ethnicity. In 1992, The European Community Arbitration Commission on 
Yugoslavia decided that the principle of uti possidetis juris applied to newly independent states. ${ }^{6}$ The application of the uti possidetis principle in the determination of new boundaries supported an image of what were perceived as 'authentic' ethnic communities. The emergent states did not adopt civic democracy; rather, elections confirmed the conflict between, on one hand, the citizens' civic or republican identity and, on the other, ethnic belonging, which, among other reasons, eventually led to the armed conflict in the 1990s. In order to end the conflict, the international community negotiated the Bosnian peace with the involvement of the leaders of ethnic-nationalist parties (Campbell 1998). The peace process consolidated a state, with power-sharing institutions, and ethno-territorial confederalism, under international administration.

\section{Significance of the Sites of Memory and Reconstruction}

The local manifestation of the international administrative powers in $\mathrm{BiH}$ is not novel, and it even has an architectural façade to cement the memory of geopolitical influences and their resurrection. The manifestation of a formal architectonic political space in the modern sovereign nation state required one constituted 'destination common to all' (Nancy 2010, p. 46). Nancy suggests that 'the combination of four terms - subject, citizen, sovereignty, community-organizes, saturates, and exhausts the political space closing itself today' (Nancy 1997, p. 103). Referring to Specters of Marx, Derrida maintains that this axiomatic still structures today the political discourse and action: it is always at work there where one appeals to the defence of the territorial identity against the other, which is lived or rather represented as the external threat justifying the closure from inside (1994). The imagination of a sovereign corresponds to the architectural 'fortress' and the political structures that close the borders as one of the pre-conditions of its survival as a sovereign entity. According to Derrida, architecture, as a distribution and organization of space, has always been connected with the affirmation of a collective identity (of a city, a people or a Nation). This identity would have always affirmed itself against the other as different, foreign, stranger and, eventually, enemy (Derrida 1986, pp. 65-75).

When observed from the interdisciplinary frame of analysis, the architectural story of the Town Hall/National Library (see Fig. 1) runs parallel to the different stages of formation of Bosnian identity. It begins with the provisions of the 1878 Treaty of Berlin, whereby $\mathrm{BiH}$ was to be occupied by the Habsburg troops for the next 30 years. The Town Hall was built in the period between 1892 and 1895 and was of exceptional importance to the Austro-Hungarian administrators. Its status as an administrative building and a site of the Bosnian Parliament was abruptly ended with the assassination of Archduke Franz Ferdinand in 1914, at its doorsteps.

Moments in the life of the Sarajevo Town Hall/National Library have been simultaneously local and transnational. The architectural, political, legal, and other narratives that surrounded the building since its establishment, show the ways in

\footnotetext{
${ }^{6}$ The European Community Arbitration Commission on Yugoslavia [1993] 92 ILR 162.
} 


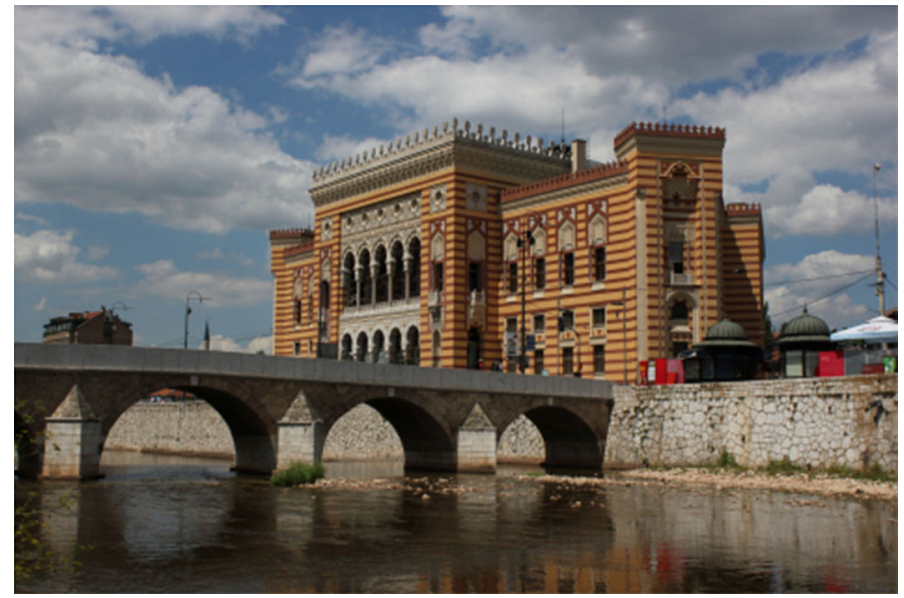

Fig. 1 Sarajevo Town Hall. 2013. http://de.wikipedia.org/wiki/Nationalbibliothek_Bosnien_und_ Herzegowina\#/media/File:Sarajevo_Vijecnica_2013.JPG

which this illusory structure took place within the broader project of the creation of national myth, memory and history. The style of the building did not originate in the local traditions, but reflected the outside perception of the Bosnian identity (Alic 2004, pp. 65-86). The lavish structure and imposing height of the Town Hall had little in common with its immediate surrounding area. Its forms incorporated the pseudo-Moorish architectural style, which originated from what the Austrian architects understood to be 'Islamic' characteristics of the local. Two-toned horizontal striations and the merlons, which created a crown around the roof of the building, referred to Mamluk architectural traditions, while lacy horseshoe arches and the slender columns seemed to be influenced by Moorish architectural practices.

The Town Hall was also to be an architectural solution between 'Western European' and 'Oriental' influences and as such was an example of the most prominent formal architectural tendencies of the Austro-Hungarian period (Sindbeak and Hartmuth 2011; Blau and Platzer 1999, pp. 25-42). The specific location of the building marked the limits of the Ottoman precinct on the west, and the entry point to the city from the east. The building became an attempt to embody the local plurality in one built whole.

As the local political structures underwent the transition of the post-Second World War Yugoslav period, the Town Hall lost its intended administrative purpose of a foreign power, and became a civic institution, the National and University Library. Architectural vision became intertwined with the socialist ideology that sought to abandon the local ethnic pluralism. Grabrijan noted that Bosnian architecture had Orientalist tendencies and sought to find rapport among modernist, nationalist, and socialist/communist agendas of the time. In particular Niedhardt was very critical of the Town Hall: 
When Austria occupied Bosnia, it looked and sought in this architecture only decorative and exotic aspects of it, and started building Moorish town halls and stations and that way demonstrated a total misunderstanding of what was local, and that [local] is very realistic and sober, free of any decoration which is not at the same time part of structure. (Grabrijan and Niedhardt 1957, p. 13)

For Niedhardt, the truer representation of local function and spirituality was the neighbouring Bascarsia precinct and its Ottoman architecture. The authentic local was to be married with the new stage of Bosnia's existence, and in line with broader Yugoslav anti-colonial ideology, participation in formation of the movement of non-aligned countries, and focused on the narrative of civic identity.

But the proposed concepts of the Yugoslav architects were replaced by ethnic and religious renewal at the beginning and closing of Bosnia's 1992-1995 war. In its most recent post-war reconstruction period, the aspects of the Town Hall's original purpose were also restored: as the ambiguous representative of local ethnic, Oriental, and European influences. Several studies have so far emphasized the role of international community in, and the transnational formation of, Bosnian political, economic and indeed, cultural institutions, as well as the protectorate-like administration of Bosnia in the present (Campbell 1998; Chandler 2000). The Town Hall has played a part in this transformation, and this can be observed from several perspectives. The building gained the status of the symbol of transnationalism, the meeting of worlds, and multiculturalism; it echoed the past and present experience of foreign administration in the region; and finally, it became a symbol for the Bosnians themselves in the new efforts to constitute a nation.

However, the Bosnian post-war rebuilding has not followed a clear, unified, or democratic process. Chandler, for instance, has argued that the historically understood meaning of democracy-legitimacy through popular accountability to the electorate, the demos - has been replaced in $\mathrm{BiH}$ by a new and opposite meaning: adherence to regulations laid down by external institutions, guided by the idea that Balkan people are unable to govern themselves. This has legitimated the growth of international mandates in the region (Chandler 2000, p. 134). Just as unclear was the application of the ECtHR Sejdic and Finci ruling, for it simultaneously sought to recognize universal understanding of a constitutional democracy, in the context of post-war state still governed as a semi-protectorate.

The critique of Bosnian current constitutional architecture can be brought together in the deconstructive approach to the Bosnian political and cultural structures. The ambiguous approach to the restructuring of the Town Hall is a symptom of a broader paradoxical and sui generis approach to $\mathrm{BiH}$ by the international community. Moreover, the very image of 'sovereign' and 'community' needs to be de-sedimented. Nancy, for instance, uses Sarajevo's ethnic fragmentation in order to address the broader problems of 'community'. His 'Eulogy' for Sarajevo is also an external analysis of its urban history and the possibilities for 'being-with' or co-existence of its inhabitants. Nancy's discussion is helpful in that it summarizes different images of Sarajevo as either space of multicultural cohabitation, or as a site of ethnic conflict. But while Nancy refers to the Heideggerian 
'being-with' of specific location, Derrida goes beyond to take apart the structures of architecture and law, and reveal their intimate connections with violence.

\section{The Mêlée}

The purposeful and violent destruction of the cultural and built heritage in $\mathrm{BiH}$ during the 1992-1995 war was a powerful reminder of the potency of architecture to carry a political message. Referring to the destroyed Town Hall/National Library, Andras Riedlmayer, expert witness to the Commission on Security and Cooperation in Europe, stated, 'Rubble in Bosnia and Herzegovina signifies nationalist extremists hard at work to eliminate not only human beings and living cities, but also the memory of the past' (Riedlmayer 1994, p. 16). This narrative emphasizes the tragedy of the local, the ethnic and the extreme. Nevertheless, the memory of the past, which Riedlmayer seems to identify, is obscure. Are those the spiritual values embedded in the historic Ottoman and Islamic built fabric? Or do they represent the change in the urban vision of modern aspirations of the socialist state? Or are they historical monuments of the Austro-Hungarian forces? Moreover, these were not only local phenomena, but an amalgam of local and international trends in architecture. But as Zizek has argued, fantasy 'emerges as a support exactly in the place where the incompleteness of reality becomes evident' (Zizek 1989, p. 44). The focus on establishing the identity of Bosnian space seeks to remember or re-create the new identity as binding material for the Bosnian populace.

In his 'Eulogy for the Mêlée', Nancy refers to Sarajevo as a place of mêlée, a mixture, crossing and a stop, a gathering (Nancy 2000, p. 145). Conquered by the Ottoman Turks in 1435, Sarajevo received its name in 1507 from the Turkish word serai, or 'palace'. It was the western outpost of the Empire facilitating communication and trade. The mixture or mélange in the city for which Nancy gives the eulogy has been that of co-existence and not mutual exclusion. Moreover, as an in-between space, it has been a place of fluidity, which resisted any impetus for homogenization.

Nancy describes and critiques a type of plurality, which led to the conflict in Sarajevo, as one caused by 'autistic multiplicity' (Nancy 2000, p. xiii). In other words, it is a reflection of a collectivity, which has an objective to enclose itself and exclude others. As such, it has been the predominant figure of community in the West and most powerfully manifested in the sovereign nation state (Nancy 2001). This immanent figure of community has impeded the 'true' thinking of community as being-together with no other essence but the co-sharing of space. Sarajevo is a point of reference, which as a city, challenges the very possibility of homogenous identity, but is besieged and forced at gunpoint into the pulling apart of its pluralism.

Nancy returns to Heidegger's discussion of Mitsein (Being-with) in Being and Time, in order to articulate an ontological foundation of being-in-common (Heidegger 1962). This is a method of walking away from the homogenizing idiom of community. His critique is directed towards a failure, evident in Sarajevo, to think of a community as being-with. Nancy emphasizes the date of his writing, 
summer of 1993, and situates his 'Eulogy' in the context of proliferating post-Cold War conflicts, understood at the time to be primarily fuelled by ethnic separatism:

These days it is not always possible to say with any assurance whether these identities are intranational, infranational, or transnational; whether they are 'cultural', 'religious', 'ethnic', or 'historical'; whether they are legitimate or not-not to mention the question about which law would provide such legitimation; whether they are real, mythical, or imaginary; whether they are independent or 'instrumentalized' by other groups who wield political, economic, and ideological power[...] This is the 'earth' we are supposed to 'inhabit' today, the earth for which the name Sarajevo will become the martyrname, the testimonial-name. (Nancy 2000, p. 145)

Elimination of an identity or definition of an identity as anomalous, results in an elimination of the participation in co-existence. But in $\mathrm{BiH}$, the ethnicization of space resulted in the 'death' or 'deconstruction' of any previous identity of that space. As Nancy writes,

those who die in Sarajevo die from the death of Sarajevo itself; they die from the possibility-imposed by gunfire-of identifying some substance or presence by this name...Those who are exiled from Sarajevo are exiled from the mix that made up Sarajevo. (Nancy 2000, p. 146)

If we follow Nancy's discussion, the re-imagining of a community as being-incommon necessitates the displacement of the mythology behind it. This thinking of being-in-common avoids the binary of friend and existential enemy, or the idea of pre-conceived coherent entities. Nancy's reflection on cities suggests that urban places represent sites of perpetual flux, thus rejecting the possibility of completeness. But it is not a mixture of pre-composed identities, or 'pure substances', which can then be mixed together, for "there has never been anything "pure" that one could or should "mix" with some other "purity" (Nancy 2000, p. 280). The thinking of 'being singular plural' is an emphasis as much on singularity as it is on plurality. Nancy thus warns against a simplistic nostalgia for the mélange:

Difference as such is indiscernible. Neither mélange nor identity can be pinned down. They have always already taken place, are always already gone, or always already still to come. And they are in common, shared by all, between all, through one another. (Nancy 2000, p. 280)

The decisive question is not the relationship between identity and plurality but a radical displacement of this opposition and its political implications and presuppositions. Thus,

there is no symmetry in this regard, no equilibrium to hold to, no fair medium. There is nothing to be discussed. The least bit of discussion, the smallest deferral to racism or to purification, in whatever form, already participates in such crime. (Nancy 2000, p. 148)

However, the political implications in Nancy's argument are not too clear. The myths behind communities emerge from multiple local-global-transnational 
processes, as in the Bosnian case, for instance. Sarajevo's death, was not a sudden death. While Nancy emphasizes the problem of community, the space he defines is not merely a tragic destruction of a Mêlée, but a situation that requires a careful historical, political, and geographical analysis. As his narrative progresses, it becomes obvious that such a Mêlée never really existed. It always had broader political, economic or strategic meaning. Bosnian constitutional history, coupled with cultural symbols such as the Town Hall/National Library, reveal this legacy. Nancy's broader critique of international legal universalism and the continuing importance of sovereignty is more applicable, because Sarajevo and its architecture also constitute a reminder of the problem of sovereignty in Europe (with emphasis on 'community') as well as the orientalist legacy. The being-with in Sarajevo's mélange was never just a mixing of individuals, but of broader geopolitical forces. The ontology of being in the world of this city, if we are to insert it into Nancy's other writing on globalization, La création du monde ou la mondialisation, is indeed not merely 'being' in the world but also having a specific meaning in the world, either as a place of meeting empires and trade, or as a situation of crisis (2002). In this sense the recollection of violence is especially necessary in the deconstructive approach.

For the international community, the events following the 1992 siege of Sarajevo created a new 'Balkan Crisis'. As cultural sites were being destroyed, they became representative images of the conflict at both local and transnational levels. As Nancy describes it, this included mapping of a City onto a Nation, onto a State, as part of both local as well as transnational processes. Moreover, in the subsequent attacks by UN forces upon it, Sarajevo became a

dimension-less point of a diagram of sovereignty, an ortho-normative gauge on a ballistic and political computer, a target frozen in a telescopic sight, and it is the very figure of the exactitude of taking aim, the pure taking aim of an essence. (Nancy 2000, p. 145)

In the struggle for immanent purity (of race, of nationhood, etc.) sovereignty became associated with disintegration. The reference to 'mêlée' should be understood in light of this emphasis, because the methodology of thinking that results in the appeal to 'ethnic and religious communities' requires profound transformation of its assumptions.

The myth of a community and its totality cannot imagine an existence outside of itself. But politics can still be retraced as the place of the exercise of power in view of an incommensurable justice - that is, as the place for claiming an infinity of being and being in the world. By definition, it does not absorb into itself all the other places of existence. In Sarajevo, or the Town Hall/National Library, an actual façade is the presence that would be remembered in terms of its own destruction.

The interpretations of the building can be incommensurable, and even its structure can change as its physical presence appears and disappears. Nancy tries to avoid the definite representation of a 'whole' as he offers a preoccupation with the 'human' (Derrida and Nancy 2004, p. 167). Namely, in order for the human being to be discovered with meaning, all claims to the truth about the nature, essence or end of human being must be undone. All meaning related to the earth or 'la terre', and 
nothing but earth and human must remain on a horizon. The infinite becomes the whole, and not only the horizon.

But Derrida has a stronger focus on the currently present structures, which need to be de-sedimented for the sake of justice. He defines architecture as 'the last fortress of metaphysics' in Point de folies-Maintenant l'architecture (1986). This perspective correlates to Derrida's determination of the Western concept and tradition of the political as 'onto-topopolitics' in the Spectres de Marx. The political has been bound to the process of a gathering within space, of the closing of borders as one of the pre-conditions of its living unity as a sovereign entity. The place and territory are essential to the constitution of the dream of the national sovereign unity keeping alterity apart. The Western tradition of the political focuses on the strengthening of the identity — of the individual and the community — to a supposed original space, to a politically and legally delineated territory separating it from the otherness in general. Derrida names onto-topology the fundamental structure of the political, as it links the ontological and metaphysical value of presence 'on' with place 'topos': 'By ontopology we mean an axiomatics linking indissociably the ontological value of present-being (on) to its situation, to the stable and presentable determination of a locality, the topos of territory, native soil, city, body in general' (Derrida 1994, p. 82).

This native soil when inserted into the supranational context of the international community also needed to gain recognition of its de jure existence. The visualization of the territory and its frontiers was always a transnational process, where local self-identification also required a corresponding external recognition. The process of Bosnian self-determination was as much a consequence of broader and selective geopolitical processes. The definition of the Balkan Crisis given by Westlake in 1905 resonates very strongly with the current crisis of the Bosnian constitution. Similarly, the international community's struggle (coupled with local demands) to define some kind of identity in this space, employed a full array of tools, including the visual and architectural. But what implications does this have for the claims of Bosnian citizens? To what extent do Nancy, Derrida or other poststructural thinkers escape a certain reliance on sovereign ipseity as the pre-condition for democracy? Does Nancy's notion of democracy as an ontological presupposition of the political reanimate our thinking of praxis, decision and resistance?

In two papers of 1991, which Derrida dedicated respectively to the reconstruction of Prague (Générations d'une ville: mémoire, prophétie, responsabilité) and to that of Berlin after the fall of the wall (Berlin Stadtforum), he insists on the interpretation of the city as the place of collective identity but also of the relation to the other (Derrida 1992). The Town Hall's relation to the local other was that of an imperial force trying to manage local identities, followed by a socialist civic insistence on transforming this object into a National Library; its destruction by Serb forces in 1992; and finally the process of reconstruction as Bosnia's own sovereignty and relation among its peoples, whereby international community and local nationalist forces have created a space of a semi-protectorate and ethno-nationalist discrimination. None of these structures acknowledge the dependency on the other, and also the responsibility to the other. But our survival depends on the other and Derrida insists on the principle of responsibility, which goes beyond Nancy's 'being-with' in 
the architecture of the future. The architect is responsible to the other to whom his project is addressed.

In response to a history of internal and external debates over, and with an imposition of, various definitions of the Bosnian identity, some Bosnian citizens have organized public protests, even if briefly and with uncertainty, to attempt to go beyond such identification of their existence. Widespread protests against unemployment and corruption began in the formerly industrial town of Tuzla in early February of 2014, and spread quickly among other cities, eventually shutting down the centre of Sarajevo. In addition, the protests quickly became interpreted as a residual echo of the armed conflict. Some of the protestors burned several buildings, including the seats of regional (cantonal) governments in the cities of Tuzla and Sarajevo. Burning buildings evoked the famous image of the 1992 shelling of the Town Hall/National Library with incendiary grenades, when its collection was destroyed. It was difficult to define the exact claims of the protestors or their identity, socioeconomic status, ethnicity and gender. The protests received very limited local and international attention, and did not result in broader political mobilization of citizens. They did, however, demonstrate a brief attempt to challenge the conservation of ethnic violence through law and foundations of the constitution.

In the situation of nationalist claims to self-determination in $\mathrm{BiH}$, religious and ethnic attributes of a society have gained international recognition as 'inevitable' components, which could not yet be replaced by the abstract citizen. The Dayton Constitution brought in an entirely new governing framework, administrative and territorial arrangement, new constitutional bodies, vertical and horizontal governing divisions, and a special package of individual and collective human rights. $\mathrm{BiH}$ became divided into three zones, and in each zone one of the three constituent peoples has an absolute majority, while other groups are minorities. This is not an insignificant restructuring considering that most of the Bosnian population did not participate in constitution-making, and the constitution was de facto adopted during peace negotiations. It is also unique because it was not officially published in the official languages of the country concerned but was agreed and published in a foreign language: English.

The mythical unitary understanding of a nation has been one of the main causes of violence in $\mathrm{BiH}$. However, while the 'sane view of international law' (to borrow Westlake's words) of the UN Charter world and in the European ECHR framework, no longer justifies ethnic discrimination, the Bosnian constitution does. The constitutional crisis of post-conflict $\mathrm{BiH}$ is a grey ambit of exception, where the international community implemented extraordinary provisions to end the conflict. These same provisions stand at the root of the constitutional instability of $\mathrm{BiH}$ and its status as a sovereign state. In a way, to keep in line with the architectural symbolism of this analysis, rather than having the Town Hall/National Library restored, the Bosnian polity would need to construct an altogether different structure. This, however, would also include not only a revisiting of its past, but a focus on the citizen demands of its present. 


\section{Conclusion}

In his teachings on architecture Grabrijan considered the study of history as the most significant aspect of his methodology. The value of the past was in its ability to illuminate the present. In the case of $\mathrm{BiH}$, the trajectory and development of the ethnic subject and the manner in which Bosnian peoples have been pulled together and/or apart in different directions throughout their history, exposes a variety of internal and external influences.

When Nancy wrote his Eulogy for Sarajevo, the city had already become 'the expression of a complete system for the reduction to identity' (Nancy 2000, p. 147). But a Eulogy is praise for someone who has passed. The image of 'death' is the current threat to local democratic initiatives in $\mathrm{BiH}$. This reduction has allowed for the escalation of violence as well as the current abandonment of the Bosnian subject before the international community. While Sarajevo's original coming into existence was 'a sign on the way, or a sign in history' as the Ottoman outpost, a century before the most recent conflict, its structure was already more than that. It was a space, which the Ottomans needed for their broader political, economic, and even symbolic interests as they reached towards the West. The subsequent AustroHungarian reconstruction of the Ottoman legacy already implied an emphasis on ethno-nationalism and geopolitical importance of the place in relation to the vanishing Ottoman Empire. The Bosnian civil war reduced it only even further, for 'Somewhere, a pure Subject declares that it is the People, the Law, the State, the Identity in the name of which "Sarajevo" must be identified purely and simply as a target' (Nancy 2000, p. 147).

The place and/or a people became purely a 'target', as Nancy describes it, due to the lack of democratic procedures during the creation of the Bosnian Constitution. But these procedures contain multiple variables, which converged into a particular political reality of contemporary $\mathrm{BiH}$. Sarajevo, however, is again seeking to enter the society of 'cosmopolitan European', even if we cannot say 're-enter' or 'exit', for it is not clear that it was ever fully accepted or excluded from the community of nations. While a Eulogy may have been appropriate in 1993, the very component of death that is embedded in the title (and for the purpose of Nancy's discussion, purely symbolic) could easily ignore the emergent spheres of political participation, especially as it is seeking to manifest itself on the ground.

This paper identified and emphasized three instances of rebuilding, remembering, and political action that insists on the affirmation of Bosnian existence. First, at the supranational level, the ECtHR decision was successful because it recognized the need for constitutional reforms. However, it did not challenge the very core of the problem: the architecture of the DPA and its inherent anti-democratic framework. The contradiction of the Bosnian constitution in its ethno-nationalist structure shows the primacy of the politics of sovereign nation-states, and the need to create a destiny common to all and for each alone, whether in the symbolic, political or religious realm.

This is where the Town Hall/National Library becomes an emblem of such representation. The building was the site of the 1910 Diet of Bosnia (Bosanski 
Sabor) where its constitutionality was declared following the Austro-Hungarian Annexation from the Ottoman Empire. The renovation of Town Hall/National Library had specific meaning. It was completed in time for the commemoration of World War I, and Sarajevo's now mythic positioning in its origins, for the assassination of Archduke Ferdinand took place as he was leaving the Town Hall on 28 June 1914.

The façade of a building is not always incommensurable. Similarly, the concepts of citizenship and sovereignty can remain open to interpretation but in themselves retain a definite understanding and functional purpose. It requires a shift into a different direction of thinking-method; a different path in and out of a structurebut it is a 'thinking'. The practice of Bosnian citizenship claims at local and supranational levels, if they were to maintain plurality, could approximate this kind of thinking. As far as the engagement of the people of Bosnia or the elected representatives is concerned, little has changed over the 10 years since the Dayton agreement. The Bosnian public has been excluded from the transition process; and while there is general support for the EU and NATO membership, there has been little public discussion of the costs and benefits involved.

The current claims of Bosnian citizens would need to result in permanent spaces for public participation. The process would be one where the people are 'constituting' and not 'constituted'. We have yet to see what it is that wishes to express itself or recognize itself in the Bosnian setting. If the present expression manages to maintain itself, it might bring in an opening for new possibilities. But the option that still remains is a hijacking or re-constitution of local demands and identities by international and local elites. And most importantly, the skeleton of democratic procedures have to be reconsidered while local voices rearrange and rebuild themselves from a history of resignation of victimhood to active participation and self-determination. The citizen with corresponding rights will always require a sovereign. But what can be an alternative? Claims articulated in Sejdic and Finci, Pilav, and Zornic require an instantiation, which will recognize all Bosnian subjects as citizens. We thus never manage to leave these spaces and their facade. In practical terms, this means undoing and dismantling the legacy of Dayton with truly participatory and democratic institutions. Importantly then, the undoing of the exiting frameworks, requires 'architectural' difference. That is to say, seeking the new method in itself, and a new authority for architectural metaphors.

Acknowledgments I thank Peter Fitzpatrck, Engin Isin, Sneja Gunew, Renisa Mawani, and Antje Wiener for the engagement with a draft, James Tully, Obiora Okafor and Umut Özsu for general suggestions, and editors and anonymous reviewers for comments.

\section{References}

Alic, Dijana. 2004. Ascribing significance to sites of memory. The Sarajevo's Town Hall. In At War with the City, ed. Paola A. Somma, 65-85. Gateshead: The Urban International Press.

Alic, Dijana. 2012. Rendered meanings: The built fabric and visions of a new socialist society in the writings of Juraj Niedhardt and Dusan Grabrijan. Fabrications: The Journal of the Society of Architectural Historians, Australia and New Zealand 21(2): 112.

Anghie, Antony. 1996. Francisco de Vitoria and the colonial origins of international law. 
Blau, Eve and Monika, Platzer. 1999. Shaping the great city: Modern architecture in central Europe, 1980-1937. Munich: Presetel Verlag.

Bosanski ustav - fototip izdanja iz 1910. godine, arr. U. Bavčić, introduction M. Imamović, Sarajevo.

Campbell, David. 1998. National deconstruction. Minneapolis: University of Minneapolis Press.

Chandler, David. 2000. Faking democracy after Dayton. London: Pluto Press.

Cirkovic, Elena. 2014. Contesting citizenship in Bosnia and Herzegovina. In Routledge handbook of global citizenship studies, ed. Engin Isin, and Peter Nyers, 455-465. New York: Routledge.

Derrida, Jacques. 1986. Point de Folie-Maintenant L'Architecture. In La Case Vide-La Villette, ed. Bernard Tschumi, 65-67. London: Architectural Association School of Architecture.

Derrida, Jacques. 1990. Force of law: The mystical foundation of authority. Cardozo Law Review 11: 921.

Derrida, Jacques. 1992. Générations d'une ville: mémoire, prophétie, responsabilités'. Prague, Avenir d'une ville historique capital. Éditions de l'aube.

Derrida, Jacques. 1994. Spectres of Marx. The state of the debt, the work of mourning and the new international. Routledge: Psychology Press.

Derrida, Jacques. 1997. In Rethinking architecture: A reader in cultural theory, part v, ed. Neil Leach, 300-328. London: Psychology Press.

Derrida, Jacques, and Peter Eisenman. 1997. In Chora L works, chap. 7, ed. Jeffrey Kipnis, and Thomas Leeser. New York: Monacelli Press.

Derrida, Jacques, and Jean-Luc Nancy. 2004. Responsabilité-Du sens à venir. In Sens en tous sens: Autour des travaux de, ed. Jean-Luc Nancy, Francis Guibal, and Jean-Clet Martin. Paris: Galilee.

Grabrijan, Dusan. 1983. The Bosnian oriental architecture in Sarajevo, with special reference to the contemporary one. Ljubljana: Dopisna Delavska.

Grabrijan, Dusan. and Niedhardt, Juraj. 1957. Arhitektura Bosne i Put u Savremeno. Ljubljana: Anon.

Heidegger, Martin. 1962. Being and time. Trans. John Maquarrie and Edward Robinson. London: Blackwell.

Howse, Robert. 1995. A horizon beyond hatred: Introductory remarks. In Yugoslavia, the former and future: Reflections by scholars from the region, ed. Payam Akhavan, and Robwet Howse. Washington: Brookings Institute.

Kennedy, David. 1996. International law and the nineteenth century: History of an illusion. Nordic Journal of International Law 65: 385.

Koskenniemi, Martti. 2001. The gentle civilizer of nations: The rise and fall of international law 1870-1960. Cambridge: Cambridge University Press.

Koskenniemi, Martti. 2011. Histories of international law: Dealing with eurocentrism. Rechtsgeschichte 19: $152-176$.

Lorimer, James. 1883. The institutes of the law of nations: A treatise on the jural relations of separate political communities. Edinburgh: W. Blackwood and Sons.

Nancy, Jean-Luc. 1993. The birth to presence. Trans. Brian Holmes, et al. Stanford: Stanford University Press.

Nancy, Jean-Luc. 1997. The sense of the world. Trans. J. Librett. Minneapolis: University of Minnesota Press.

Nancy, Jean-Luc. 2000. Eulogy for the Mêlée. In Being singular plural. Trans. Robert D. Richardson and Anne O'Byrne. Stanford: Stanford University Press.

Nancy, Jean-Luc. 2001. La Communauté affrontée. Paris: Éditions Galilée.

Nancy, Jean-Luc. 2010. The truth of democracy. New York: Fordham University Press.

Orford, Anne. 2014. Scientific reason and the discipline of international law. European Journal of International Law 35: 369-385.

Özsu, Umut. 2013. A thoroughly bad and vicious solution: Humanitarianism, the world court, and the modern origins of population transfer. London Review of International Law 1: 99-127.

Riedlmayer, Andras. 1994. Killing memory: The targeting of libraries and archives in BosniaHerzegovina. Newsletter of Middle East Libraries Association 61(1): 16.

Schmitt, Carl. 2003. [1950] The nomos of the earth in the international law of the Jus Publicum Europaeum. Trans. G.L. Ulmen. New York: Telos Press Publishing.

Simpson, Gerry. 2004. Great powers and outlaw states: Unequal sovereigns in the international legal order. Cambridge: Cambridge University Press.

Sindbeak, Tea, and Maximilian Hartmuth (eds.). 2011. Images of imperial legacy: Modern discourses on the social and cultural impact of Ottoman and Habsburg rule in Southeast Europe. Berlin: Lit Verlag. 
Sorenson, Peter. 2012. EU and BiH sign protocol for the reconstruction of the City Hall in Sarajevo and City Hall in Novi Grad. Delegation of the European Union to Bosnia and Herzegovina and European Union Special Representative.

Symonds, Arthur J. 1914. The Balkan Committee, 1905-1913, in Memories of John Westlake. http:// archive.org/stream/memoriesofjohnwe00willuoft\#page/110/mode/2up.

Wallerstein, Immanuel. 1976. Semi-peripheral countries and the contemporary world crisis. Theory and Society 3: 461.

Westlake, John. 1894. Chapters on the principles of international law. New York: Macmillan.

Zizek, Slavoj. 1989. The Sublime object of ideology. Verso. 